\title{
Seasonal variation of allochthonous and autochthonous energy inputs in an Alpine stream
}

\author{
Stefano FENOGLIO, ${ }^{1 *}$ Tiziano BO, ${ }^{1}$ Massimo CAMMARATA, ${ }^{1}$ Manuel J. LÓPEZ-RODRÍGUEZ, ${ }^{2}$ \\ José M. TIERNO DE FIGUEROA ${ }^{3}$
}

\begin{abstract}
${ }^{1}$ Dipartimento di Scienze e Innovazione Tecnologica, Università del Piemonte Orientale, via Teresa Michel 11, 15100 Alessandria, Italy; ${ }^{2}$ Departamento de Ecología, Facultad de Ciencias, Universidad de Granada, Campus Fuentenueva s/n, 18071 Granada, Spain ${ }^{3}$ Departamento de Zoología, Facultad de Ciencias, Universidad de Granada, Campus Fuentenueva s/n, 18071 Granada, Spain *Corresponding author: fenoglio@unipmn.it
\end{abstract}

\begin{abstract}
Despite the enormous importance of alpine streams, information about many aspects of their ecology is still insufficient. Alpine lotic systems differ in many environmental characteristics from those lower down, for example because above tree line streams drain catchments where terrestrial vegetation is scarce and allochthonous organic input is expected to be small. The main objectives of this study were to examine seasonal variation of autochthonous and allochthonous energetic inputs and their relationship with macroinvertebrate communities in the Po River, an alpine non-glacial stream (NW Italy). For one year, samplings were monthly performed in a homogeneous $100 \mathrm{~m}$ stream reach for discharge, autochthonous energy input (benthic chlorophyll a), allochthonous energy input (coarse particulate organic matter), abundance and structure of benthic macroinvertebrate community. Chlorophyll a concentrations were in the range of what reported for other alpine streams, but presented a time-lag with respect to what has been reported for glacial-fed mountain rivers. CPOM amounts were lower than those in lowland, forested streams of the same area but exhibited an intriguing, different seasonal variability, probably reported for the first time, with a maximum in spring and a minimum in winter. We collected 29,950 macroinvertebrates belonging to 13 families and 10 orders. Benthic communities were essentially dominated by Ephemeroptera, Plecoptera and Diptera. Scrapers were the most important FFG, but also shredders were well represented. Relationships between chlorophyll a concentrations, CPOM availability and macroinvertebrate community characteristics were analysed and discussed considering the existence of different top-down or bottom-up regulation mechanisms. This study confirms that benthic algae constitute an essential resource for macroinvertebrates in alpine streams above the tree line but also underlines the importance of terrestrial organic input, a previously neglected input in environments above the tree line. The major forces shaping energetic inputs and invertebrate communities seemed to be related to the Alpine climate, and especially to snow accumulation and melting, with the consequent substantial discharge variations.
\end{abstract}

Key words: Alpine stream, allochthonous inputs, autochthonous inputs, Po River, benthic macroinvertebrates.

Received: August 2014. Accepted: October 2014.

\section{INTRODUCTION}

Alpine streams are important aquatic systems, hosting an unique set of ecosystems and species, representing early and delicate phases of the freshwater cycle (Ward, 1994), and constitute interesting environments for scientific and recreational purposes. Environmental characteristics of Alpine lotic systems differ from low-land habitats: they generally have cold, highly oxygenated and turbulent water, steep gradients, coarse substrata, low channel stability, limited nutrients and organic matter availability, and a shorter growing season (Mani, 1990; Hieber et al., 2002).

Various typologies of streams can be identified in the Alps. Kryal streams, of glacial origin, have low water temperatures, high concentrations of suspended particles, and higher channel instability (Milner et al., 2010). Because of their uniqueness, their extreme sensitivity to climate change, and their affinities to arctic streams, study efforts on Alpine kryal systems have recently increased (Maiolini and Lencioni, 2001; Jacobsen and Dangles, 2012). However, in the Alps these systems are less common than other stream types, which still remain little studied, such as krenal (groundwater-fed) and rhithral (snow-fed) streams (Ward, 1994).

Improving our knowledge on the ecology of Alpine streams is important, because these environments are subject to an increasing human pressure (Maiolini and Bruno, 2007; Bizzotto et al., 2009), such as widespread distribution of hydroelectric facilities, water diversion for irrigation, drinking, snow making, and other uses (Bruno et al., 2010; Zolezzi et al., 2011) and channel alterations (Bona et al., 2008). Moreover, these direct human impacts should be considered in the broader context of global climate change. Alpine aquatic environments are extremely sensitive to climate change; warming events reduce snowpack and ice cover and increase water temperatures (Brown et al., 2007), with important hydrological, mor- 
phological and ecological consequences, such as biodiversity loss and decreased functional efficiency (Acuña et al., 2008; Milner et al., 2009; Finn et al., 2012).

Since the formulation of the River Continuum Concept (RCC; Vannote et al., 1980) it is well known that the main energy source of small, low-order lotic systems is constituted by allochthonous inputs of organic matter, mainly terrestrial leaves (Gessner et al., 1999; Tank et al., 2010). Streams in mountainous regions could represent an exception: above the tree line, a ragged line that separates areas with different growth limiting factors for trees (Körner, 1998), stream catchments have scarce terrestrial vegetation, and consequently reduced input of allochthonous organic matter. Although Alpine streams are important ecosystems, threated by human impacts and climate change, little information is available on the balance of allochthonous and autochthonous energy inputs. The main objectives of this study were: i) to describe seasonal variation of in-stream benthic chlorophyll $a$ and coarse particulate organic matter amounts over an annual cycle; ii) to analyse the relationships between these energy inputs and the characteristics of the macroinvertebrate community in an Alpine non-glacial stream.

\section{METHODS}

\section{Study site}

The Po River is the longest Italian lotic system (652 $\mathrm{km}$ ). It rises from a spring below the northwest side of the Monviso Mountain, in the Cottian Alps of north-western Italy. The study site was located at Pian della Regina (1750 m asl, UTM 357750-4951547, Crissolo, NW Italy - Fig. 1), 2.5 kilometres downstream from the spring. Here, the Po River is a typical second order mountain stream, with a catchment area of approximately $16.0 \mathrm{~km}^{2}$ that ranges from an altitude of 1750 to $3841 \mathrm{~m}$ asl. Many lakes of glacial origin are present in the highest area of the catchment but have no direct surface connections to the Po River. At the study site, the stream is an open system flowing across a plain of glacial origin, characterized by extensive Alpine meadows pointed by large erratic boulders and scattered Larix decidua Mill., 1768. Riparian vegetation is composed almost exclusively by Poaeceae and Ericaceae.

The study was performed realising monthly samplings in a homogeneous $100 \mathrm{~m}$ stream reach. Substrate in the study site was homogeneous and composed mainly by

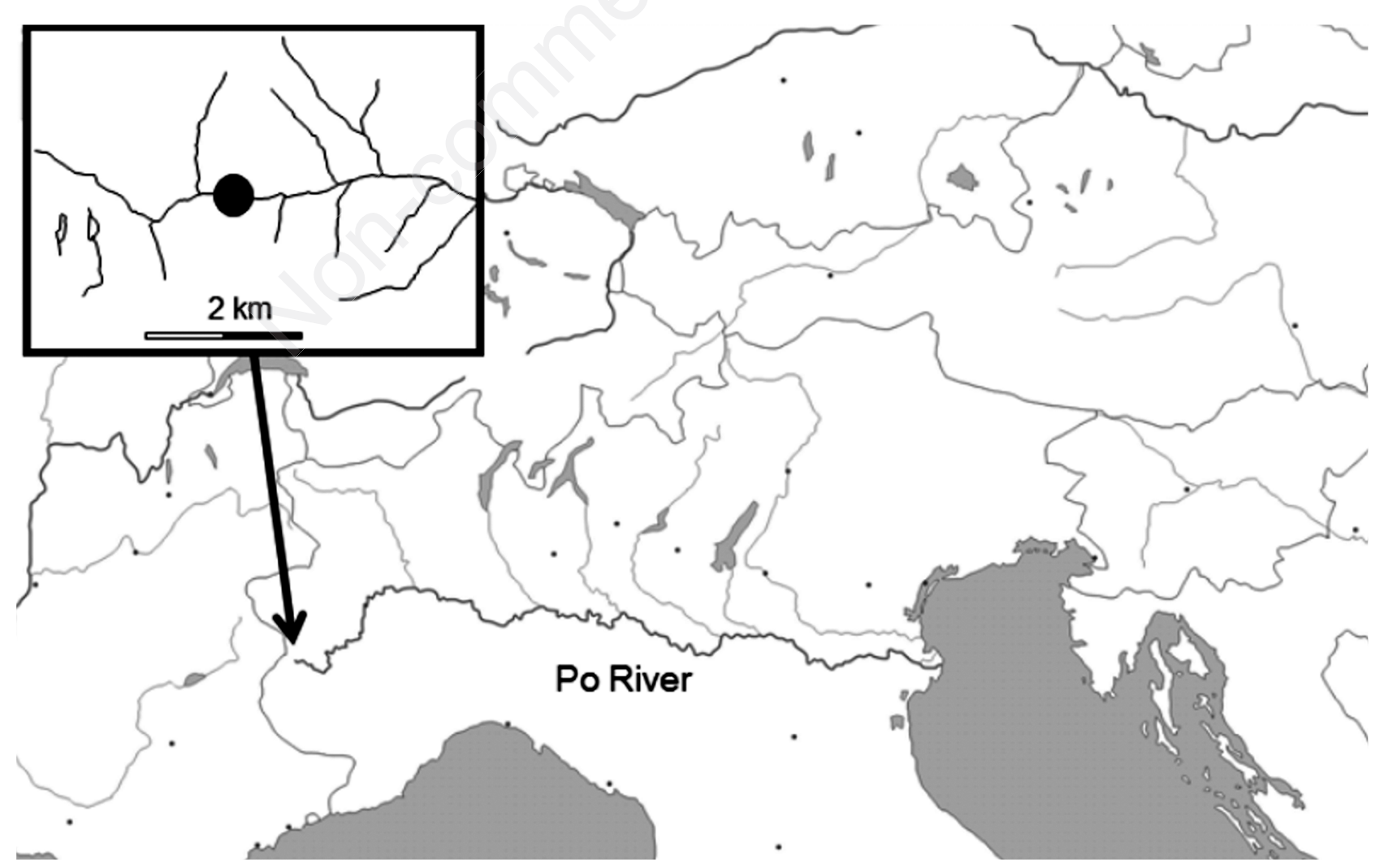

Fig. 1. Po River and the location of Pian della Regina (Crissolo, Cuneo). 
coarse elements (approximately boulders $50 \%$, cobbles $40 \%$, gravel $10 \%$ ).

\section{Physical-chemical characteristics}

Water temperature was measured hourly with a datalogger (HOBO ${ }^{\circledR}$ Water Temp Pro, $0.01^{\circ} \mathrm{C}$ accuracy). Conductivity, dissolved oxygen, $\mathrm{pH}$, chemical oxygen demand (COD), biochemical oxygen demand (BOD), total phosphorus, discharge, streambed width and water column height were measured on each sampling date (Tab. 1).

\section{Benthic macroinvertebrates}

Benthic samples were collected monthly from January to December 2010 using a Surber net ( $250 \mu \mathrm{m}$ mesh size; $0.062 \mathrm{~m}^{2}$ area). Eight samples were collected randomly during each sampling date, accounting for a total area of $0.50 \mathrm{~m}^{2}$. The substrate collected, including macroinvertebrates, was mixed and stored in plastic jars containing $4.0 \%$ formalin. The location of each Surber sample was recorded and a recolonisation period of a minimum of two months was allowed between collection events. Organisms were counted in the laboratory, using a Nikon SMZ 1500 stereomicroscope, and identified to species or genus level, except for some Trichoptera, Coleoptera and Diptera, which were identified to the family level using taxonomic keys (Ruffo, 1977-1985, Campaioli et al., 1994, 1999). To assess the trophic characteristic of the community, each taxon was assigned to a Functional Feeding Group (FFG: scrapers, shredders, collector-gatherers, filterers and predators) according to Merritt and Cummins (1996).

\section{Allochthonous inputs}

Coarse particulate organic matter (CPOM) collected in the Surber samples was hand-sorted and divided into two categories: larch (L. decidua) litter and other CPOM (grass fragments, leaf litter, and miscellaneous organic particles), to account for the different palatability of coniferous litter to macrobenthonic fauna (Campos and González, 2009; Collen et al., 2004). In the laboratory, larch litter and the other СРОM were air dried for $24 \mathrm{~h}$, oven dried $\left(105^{\circ} \mathrm{C}\right)$ for additional $24 \mathrm{~h}$, and weighed with an electronic scale (accuracy $\pm 0.001 \mathrm{~g}$ ).

\section{Autochthonous inputs}

Autochthonous inputs were assessed by measuring chlorophyll $a$, according to Uehlinger et al. (1998). During the monthly samplings, ten boulders were randomly chosen and algal film was collected from an area of 256 $\mathrm{cm}^{2}(16 \times 16 \mathrm{~cm})$ using a brush. The samples were transferred into opaque falcon tubes with $20 \mathrm{~mL}$ of deionised water, and transported in ice to the laboratory. Chlorophyll $a$ was extracted in $90 \%$ acetone according to Steinman and Lamberti (1996) and its concentration measured using a DUSERIES 500 Beckman spectrophotometer.

\section{RESULTS}

During the study, mean stream width and water depth were $5.13 \mathrm{~m}$ and $24 \mathrm{~cm}$, with a maximum of $7.5 \mathrm{~m}$ and $51 \mathrm{~cm}$ and a minimum of $3.75 \mathrm{~m}$ and $0.11 \mathrm{~cm}$, respectively. Water temperature varied considerably (Fig. 2), with a mean annual temperature of $4.40^{\circ} \mathrm{C}$, a minimum of $0.01^{\circ} \mathrm{C}$ in January, February and December and a maximum of $13.0^{\circ} \mathrm{C}$ in mid-August. Discharge was highest in spring and early summer following snowmelt; mean discharge was $0.49 \mathrm{~m}^{3} / \mathrm{s}$, with a minimum in December $(0.07$ $\left.\mathrm{m}^{3} / \mathrm{s}\right)$ and a maximum in May $\left(1.78 \mathrm{~m}^{3} / \mathrm{s}\right.$ - Fig. 2). Chemical characteristics are in the range of what reported for similar lotic environments in this Alpine area (Fenoglio et al., 2007).

\section{Autochthonous inputs}

A total of 120 benthic algae samples were examined (ten samples per month). Mean annual benthic chlorophyll $a$ concentration was $0.25( \pm 0.11 \mathrm{SD}) \mu \mathrm{g} / \mathrm{cm}^{2}$. Sig-

Tab. 1. Main physical-chemical parameters of the Po River during the study period (mean $\pm \mathrm{SD}$ ).

\begin{tabular}{lc} 
Parameter & Values \\
Conductivity $(\mu \mathrm{S} / \mathrm{cm})$ & $95.4 \pm 2.94$ \\
Dissolved oxygen $(\mathrm{mg} / \mathrm{L})$ & $10.3 \pm 3.32$ \\
\hline $\mathrm{pH}$ & $7.53 \pm 0.10$ \\
$\mathrm{COD}(\mathrm{mg} / \mathrm{L})$ & $<5$ \\
\hline BOD $(\mathrm{mg} / \mathrm{L})$ & $<2$ \\
Total phosphorus $(\mathrm{mg} / \mathrm{L})$ & $<0.05$ \\
\hline Flow speed $(\mathrm{m} / \mathrm{s})$ & $0.43 \pm 0.15$ \\
Discharge $\left(\mathrm{m}^{3} / \mathrm{s}\right)$ & $0.48 \pm 0.59$ \\
\hline
\end{tabular}

$C O D$, chemical oxygen demand; $B O D$, biochemical oxygen demand.

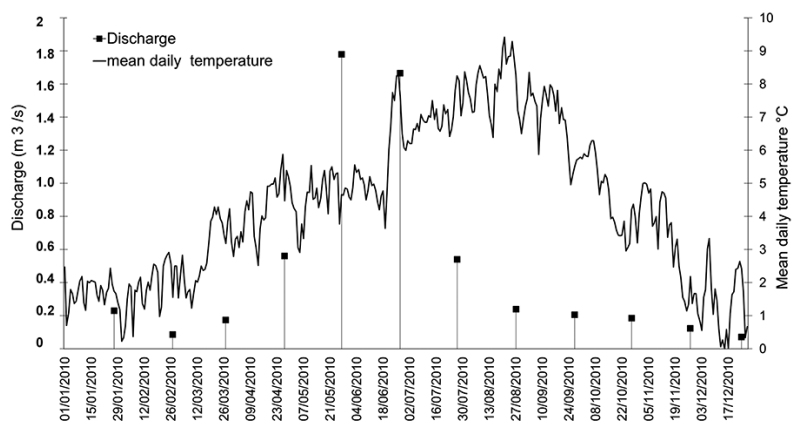

Fig. 2. Seasonal variation of water temperature and discharge in Pian della Regina (Crissolo, Cuneo). 
nificant monthly differences were detected in the concentration of this pigment (Friedman ANOVA $\mathrm{F}=47.2$, $\mathrm{P}<0.001$; Fig. 3): chlorophyll $a$ values were lowest in late spring $\left(0.03 \mu \mathrm{g} / \mathrm{cm}^{2} \pm 0.02 \mathrm{SD}\right.$ in June $)$ and winter $(0.13$ $\left.\mu \mathrm{g} / \mathrm{cm}^{2} \pm 0.08 \mathrm{SD}\right)$ and increased significantly to a peak in the late summer $\left(0.42 \mu \mathrm{g} / \mathrm{cm}^{2} \pm 0.10 \mathrm{SD}\right.$ in August and similar values in July).

\section{Allochthonous inputs}

The mean weight of benthic coarse particulate organic matter was $11.4 \mathrm{~g} / \mathrm{m}^{2}( \pm 15.6 \mathrm{SD}$ dry mass). Total amount of CPOM in the streambed showed high seasonal variability, with a maximum in May $\left(58.2 \mathrm{~g} / \mathrm{m}^{2}\right)$ and a minimum in December $\left(1.40 \mathrm{~g} / \mathrm{m}^{2}\right)$. At the study site, CPOM was mostly constituted by grass fragments, vegetal particles and small roots. Larch litter constituted only the $6.6 \%$ of the total CPOM, with a minimum in July $\left(0.04 \mathrm{~g} / \mathrm{m}^{2}\right)$ and a maximum in November $\left(2.25 \mathrm{~g} / \mathrm{m}^{2}\right.$ - Fig. 4).

\section{Macroinvertebrate community}

We collected 29,950 organisms belonging to 44 aquatic taxa, representing 13 families from 10 orders (Ephemeroptera, Plecoptera, Trichoptera, Diptera, Coleoptera, Tricladida, Haplotaxida, Lumbriculida, Heterostropha, Basommatophora). Macroinvertebrate density was $4317.5 \pm 617.7$ ind $\mathrm{m}^{-2}$ (mean $\pm \mathrm{se}$ ). Benthic communities were dominated by aquatic insects $(96.3 \%$ of total abundance), mainly represented by Ephemeroptera (38.0\%), Plecoptera (29.8\%), and Diptera (22.2\%). The most abundant FFG was scrapers (40.1\%), followed by shredders $(28.4 \%)$, collector-gatherers $(16.8 \%)$, and predators $(10 \%)$. Filterers accounted for only the $4.1 \%$ of total invertebrate number, and were almost exclusively represented by Diptera Simuliidae. The amount of CPOM was positively and significantly correlated with taxonomic richness ( $\mathrm{S}$ : Spearman $\mathrm{R}=0.67, \mathrm{P}<0.05$ ), macroinvertebrate abundance $(\mathrm{N}$ : Spearman $\mathrm{R}=0.69, \mathrm{P}<0.05)$, and shredder density (Spearman $\mathrm{R}=0.76 ; \mathrm{P}<0.05$ ). However, no significant correlations were found between chlorophyll $a$ concentrations and the same parameters (S: Spear$\operatorname{man} \mathrm{R}=-0.14 ; \mathrm{P}>0.05 ; \mathrm{N}$ : Spearman $\mathrm{R}=0.22 ; \mathrm{P}>0.05 ; \mathrm{Sh}$ : Spearman $\mathrm{R}=0.25 ; \mathrm{P}>0.05$ ), although we noticed a tendency of scrapers to increase with increased chlorophyll $a$ availability, even if not statistically significant (Sc: Spearman $\mathrm{R}=0.31 ; \mathrm{P}>0.05)$.

\section{DISCUSSION}

At the study site, the Po River was characterized by elevated variability in discharge, streambed width, and temperature during the study period. Mean chlorophyll $a$ values were in the range of what reported in other studies regarding mountain lotic systems (Hauer et al., 2007), but slightly lower compared to values reported by Lods-
Crozet et al. (2001) for a Swiss glacial stream at the same altitude. Seasonal patterns of chlorophyll $a$ presented a time-lag compared to what reported for glacial-fed streams, where the lowest values of chlorophyll $a$ are in the summer (July and August) when, despite elevated light availability, high temperatures favour ice melt which in turn increases fine particulate transport, shear stress, abrasion and turbidity (Uehlinger et al., 1998; Rott et al., 2006; Uehlinger et al., 2010, Bona et al., 2011). At our study site, chlorophyll $a$ concentrations reached the lowest values in June and peaked in August. Because of the absence of glaciers, snowmelt and therefore discharge increase resulted more anticipated and concentrated than in kryal environments (Rott et al., 2006). A second negative peak occurred in the winter, when, due to reduced daylength and geographic position of the site, light availability was at its minimum. The coarse particulate organic matter availability and its variation in catchments lacking forest canopies are poorly studied compared to those of other regions (e.g., forested streams - see review in Tank

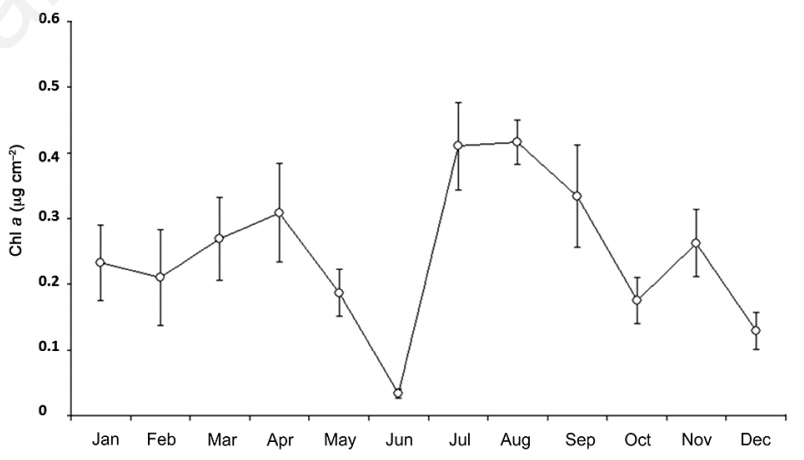

Fig. 3. Seasonal variation of benthic chlorophyll $a$ concentrations at the study site.

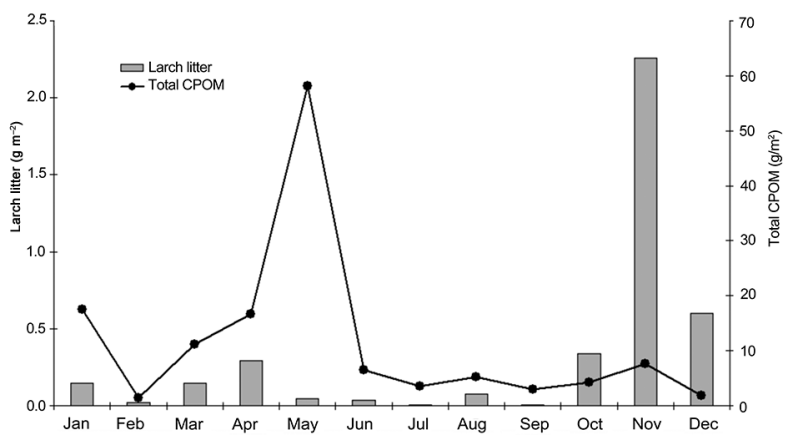

Fig. 4. Seasonal variation of coarse particulate organic matter (CPOM) at the study site (total CPOM and the fraction composed by larch litter are depicted). 
et al., 2010). In deciduous forested temperate catchments, CPOM availability is highly seasonal with the highest amounts recorded during autumn and winter (Benfield, 1997; Fenoglio et al., 2005).

In our study site, CPOM amount was generally lower than in lowland, forested streams of the same area (Fenoglio et al., 2005), and showed high seasonal variability, with highest values in the spring. This pattern contrasted what observed in lowland streams, where the peak in abundance of CPOM was recorded in autumn (Allan and Castillo, 2007). In our study only larch litter, a small percentage of total CPOM, had an autumn peak, because larch is a deciduous conifer. We hypothesized that the observed CPOM trend was related to climatic and environmental factors: above the tree line, terrestrial vegetation is constituted mainly by alpine prairie and scattered small shrubs; in the cold season, decaying organic matter is trapped under the snow cover. During the spring thaw, meltwater collects and transports grass fragments and other coarse organic particles from throughout the catchment to the stream.

Benthic macroinvertebrate communities were dominated by orophilous, specialized taxa, with high diversity and abundance of Plecoptera, Ephemeroptera, and cold stenothermic Diptera. Scrapers were the most abundant Functional Feeding Group, suggesting that primary autochthonous production represented a major energetic input in this environment. Filterers are relatively poorly represented probably because, according to the general statements of the RCC (Vannote et al., 1980), fine particulate organic matter is expected to be scarce in mountain headwaters. Abundance and functional composition of macroinvertebrate communities were in the range of what observed in similar Alpine environments (Fenoglio et al., 2007; Lencioni et al., 2011). However, it is difficult to find direct and clear relationships between the variation of observed parameters (chlorophyll $a$ and CPOM availability) and characteristics of macrobenthic communities, as the latters are influenced by a larger number of factors (Allan and Castillo, 2007). However, the lack of significant relationships between algal availability and macroinvertebrate community descriptors, in particular grazers abundance, could be due to a top-down regulation mechanism where scrapers reduced significantly the amounts of benthic chlorophyll a (Brown et al., 2000; Hillebrand, 2002). On the contrary, detritivorous macroinvertebrates are part of a typical donor type system and show an evident bottom-up regulation; i.e., the availability of the resource limits the abundance of consumers (Dobson and Hildrew, 1992).

\section{CONCLUSIONS}

This study reports one of the first descriptions of the seasonal variations of allochthonous and autochthonous energy inputs in a non-glacial, Alpine stream, with some notes about their relationships with macrobenthic communities. In this context, the most important factors are likely related to climate, especially snow accumulation and meltdown, which consequently promotes substantial discharge variation, abrasion of the substrate and collecting of huge amounts of terrestrial organic matter from the catchment. These factors influence both the autochthonous production and the amount of allochthonous organic input, which has a different trend to what usually happens in lower altitude, forested river systems. The macrobenthic community that characterized the Po River at the study site consisted of stenoecious, specialized taxa that are able to exploit the limited resources of this harsh environment. A better understanding of ecological dynamics and the effects of climate and hydrology on the biota of Alpine rivers is essential for management and planning, in an era when Alpine lotic systems are facing increasing direct anthropogenic impacts and the evolving meteorological patterns associated with the undergoing global climate change.

\section{ACKNOWLEDGMENTS}

We are grateful to Massimo Pessino for useful suggestions. This study was supported by grants from the Parco del Po Cuneese and the Fondazione Cassa di Risparmio di Alessandria CRAL.

\section{REFERENCES}

Acuña V, Wolf A, Uehlinger U, Tockner K, 2008. Temperature dependence of stream benthic respiration in an Alpine river network under global warming. Freshwater Biol. 53:2076-2088.

Allan JD, Castillo MM, 2007. Stream ecology: structure and function of running waters. Springer, Dordrecht: $436 \mathrm{pp}$.

Benfield EF, 1997. Comparison of litterfall input to streams. J. N. Am. Benthol. Soc. 16:04-108.

Bizzotto EC, Villa S, Vighi M, 2009. POP bioaccumulation in macroinvertebrates of alpine freshwater systems. Environ. Poll. 157:3192-3198.

Bona F, Falasco E, Fenoglio S, Iorio L, Badino G, 2008. Response of macroinvertebrate and diatom communities to human-induced physical alteration in mountain streams. Riv. Res. Appl. 24:1068-1081.

Bona F, La Morgia V, Falasco E, 2011. Predicting river diatom removal after shear stress induced by ice melting. Riv. Res. Appl. 28:1289-1298.

Brown GG, Norris RH, Maher WA, Thomas K, 2000. Use of electricity to inhibit macroinvertebrate grazing of epilithon in experimental treatments in flowing waters. J. N. Am. Benthol. Soc. 19:176-185.

Brown LE, Hannah DM, Milner AM, 2007. Vulnerability of alpine stream biodiversity to shrinking glaciers and snowpacks. Glob. Change Biol. 13:958-966.

Bruno C, Maiolini B, Carolli B, Silveri L, 2010. Short time-scale impacts of hydropeaking on benthic invertebrates in an Alpine stream (Trentino, Italy). Limnologica 40:281-290. 
Campaioli S, Ghetti P F, Minelli A, Ruffo S, 1994. [Manuale per il riconoscimento dei macroinvertebrati delle acque dolci italiane, I].[Book in Italian]. Provincia Autonoma di Trento, Trento: $357 \mathrm{pp}$.

Campaioli S, Ghetti P F, Minelli A, Ruffo S, 1999. [Manuale per il riconoscimento dei macroinvertebrati delle acque dolci italiane, II].[Book in Italian]. Provincia Autonoma di Trento, Trento: $126 \mathrm{pp}$.

Campos J, González JM, 2009. Sericostoma vittatum (Trichoptera) larvae are able to use pine litter as an energy source. Int. Rev. Hydrobiol. 94:472-483.

Collen P, Keay EJ, Morrison BRS, 2004. Processing of pine (Pinus sylvestris) and birch (Betula pubescens) leaf material in a small river system in the northern Cairngorms, Scotland. Hydrol. Earth Syst. Sci. 8:567-577.

Dobson M, Hildrew AG, 1992. A test of resource limitation among shredding detritivores in low order streams in southern England. J. An. Ecol. 61:69-77.

Fenoglio S, Bo T, Agosta P, Malacarne G, 2005. Temporal and spatial patterns of coarse particulate organic matter and macroinvertebrate distribution. J. Freshwat. Ecol. 20:539-547.

Fenoglio S, Bo T, Malacarne G, 2007. Preimaginal feeding habits of Dictyogenus fontium (Plecoptera, Perlodidae) in an alpine brook in NW Italy. Ent. Fenn 18: 27-31.

Finn DS, Khamis K, Milner AM, 2012. Loss of small glaciers will diminish beta diversity in Pyrenean streams at two levels of biological organization. Global Ecol. Biogeogr. 22:40-51.

Gessner MO, Chauvet E, Dobson M, 1999. A perspective on leaf litter breakdown in streams. Oikos 85:377-384.

Hauer FR, Stanford JA, Lorang MS, 2007. Pattern and process in Northern Rocky Mountain headwaters: Ecological linkages in the headwaters of the crown of the continent. J. Am. Water Works. Ass. 43:104-117.

Hieber M, Robinson CT, Uehlinger U, Ward JV, 2002. Are alpine lake outlets less harsh than other alpine streams? Arch. Hydrobiol. 154:199-223.

Hillebrand H, 2002. Top-down versus bottom-up control of autotrophic biomass-a meta-analysis on experiments with periphyton. J. N. Am. Benthol. Soc. 21:349-369.

Jacobsen D, Dangles O, 2012. Environmental harshness and global richness patterns in glacier-fed streams. Global Ecol. Biogeogr. 21:647-656.

Körner C, 1998. A re-assessment of high elevation treeline position and their explanation. Oecologia 115:445-459.

Lencioni V, Marziali L, Rossaro B, 2011. Diversity and distribution of chironomids (Diptera, Chironomidae) in pristine Alpine and pre-Alpine springs (Northern Italy). J. Limn. 70:106-121.

Lods-Crozet B, Castella E, Cambin D, Ilg C, Knispel S, Mayor-
Simeant H, 2001. Macroinvertebrate community structure in relation to environmental variables in a Swiss glacial stream. Freshwater Biol. 46:1641-1661.

Maiolini B, Lencioni V, 2001. Longitudinal distribution of macroinvertebrate assemblages in a glacially influenced stream system in the Italian Alps. Freshwater Biol. 46:1625-1639.

Maiolini B, Bruno MC, 2007. The River Continuum Concept revisited: lessons from the Alps, p. 67-76. In: R. Psenner and R. Lackner (eds.) Alpine space - man \& environment. The Water Balance of the Alps. Innsbruck University Press.

Mani MS, 1990. Fundamentals of high altitude biology. Oxford \& IBH Publ.: 138 pp.

Merritt RW, Cummins KW, 1996. An introduction to the aquatic insects of North America. Kendall / Hunt Publ.: 862 pp.

Milner AM, Brown LE, Hannah DM, 2009. Hydroecological response of river systems to shrinking glaciers. Hydrol. Process. 23:62-77.

Milner AM, Brittain JE, Brown LE, Hannah DM, 2010. Water sources and habitat of Alpine streams. Handbook Env. Chem. 6:175-191.

Rott E, Cantonati M, Füreder L, Pfister P, 2006. Benthic algae in high altitude streams of the Alps - a neglected component of the aquatic biota. Hydrobiologia 562:195-216.

Ruffo S, 1977-1985. [Guide per il riconoscimento delle specie animali delle acque interne italiane]. 30 Volumes [Book Series in Italian]. CNR, Rome.

Steinmann AD, Lamberti GA, 1996. Biomass and pigments of benthic algae, p. 295-313. In F.R. Hauer and G. Lamberti G (eds.), Methods in Stream Ecology. Academic Press.

Tank JL, Rosi-Marshall EJ, Griffiths NA, Entrekin SA, Stephen ML, 2010. A review of allochthonous organic matter dynamics and metabolism in streams. J. N. Am. Benthol. Soc. 29:118-146.

Uehlinger U, Robinson CT, Hieber M, Zah R, 2010. The physico-chemical habitat template for periphyton in alpine glacial streams under a changing climate. Hydrobiologia 657:107-121.

Uehlinger U, Zah R, Burgi H, 1998. The Val Roseg project: Temporal and spatial patterns of benthic algae in an alpine stream ecosystem influenced by glacier runoff. IAHS Pub. 248:419-424.

Vannote RL, Minshall GW, Cummins KW, Sedell JR, Cushing CE, 1980. The River Continuum Concept. Can. J. Fish. Aquat. Sci. 37:130-137.

Ward JV, 1994. Ecology of alpine streams. Freshwater Biol. 32:277-294.

Zolezzi G, Siviglia A, Toffolon M, Maiolini B, 2011. Thermopeaking in alpine streams: event characterization and time scales. Ecohydrology 4:564-576. 